\title{
Erratum to: Inhospitable Healthcare Spaces: Why Diversity Training on LGBTQIA Issues Is Not Enough
}

\author{
Megan A. Dean • Elizabeth Victor • Laura Guidry-Grimes
}

Published online: 31 January 2017

(C) Journal of Bioethical Inquiry Pty Ltd. 2017

\section{Erratum to: Bioethical Inquiry}

DOI 10.1007/s11673-016-9738-9

The 3rd author name is missing a hyphen and should be Laura Guidry-Grimes.

The online version of the original article can be found at http://dx. doi.org/10.1007/s11673-016-9738-9.

M. A. Dean $(\bowtie)$

215 New North Hall, 37th and O Streets, N.W., Washington, DC 20057, USA

e-mail:mad301@georgetown.edu

E. Victor

William Paterson University, 300 Pompton Rd, Wayne, NJ 07470, USA

L. Guidry-Grimes

Medstar Washington Hospital Center and Georgetown University, 110 Irving St NW, East Building, Room 3108, Washington, DC 20010, USA 